\title{
Foodservice Management of Health Industries Based on Customer Satisfaction
}

\author{
Sheng Zhong ${ }^{1, *}$, Lu Hou ${ }^{1}$, Zhiyong $\mathrm{Rao}^{2}$, Wen $\mathrm{Hu}^{2}$ \\ 1. Business School, Sichuan University, Chengdu, China \\ zhshescu.edu.cn \\ 2. Department of Clinical Nutrition, West China Hospital of Sichuan University, Chengdu, \\ China
}

\begin{abstract}
To support managerial decision making, this paper investigates the linkages among service, timeliness, product quality, price reasonableness, and customer satisfaction in a hospital. Considering the practical needs, we proposed STQP-SERVQUAL (customer satisfaction model of hospital foodservice) on the basement of SERVQUAL. Data from 281 questionnaires was analyzed. Using structural equation modeling, the results suggest that service, timeliness, and product quality have a positive significant impact on patients' satisfaction with hospital foodservice. Moreover, the impact caused by price reasonableness is not significant. But price reasonableness is the lowest satisfied factor; it also calls for managers' attention. Theoretical and managerial implications are discussed. Although the case study is in a large hospital, the application of the results can be extended to other health industries.
\end{abstract}

Keywords: foodservice; customer satisfaction; SEM; SERVQUAL

\section{Introduction}

Since the enhancement of health care reform, people have paid more attention to hospital service quality. The demand for supportive service (e.g. foodservice) is increasing. However, according to some satisfaction researches [1,2], foodservice is one of the most dissatisfied parts in Chinese hospital service. Although the main purpose for going to see a doctor is to treat symptoms, supportive service becomes an important part that patients will consider. They have already felt discomfort because of their disease, and then nobody wants to experience a bad service either. High-quality service has become a requirement among hospitals [3]. To support managerial decision making, it's necessary to study on the factors which influence patient's satisfaction with hospital foodservice, and the influence degree of each factor.

Customer satisfaction involves an attitude or judgment toward a product or service that successfully provides a pleasurable level of consumption-related fulfillment [4]. Customer satisfaction is related to economic return [5,6]. And economic return spurs an organization to develop. It's essential to study customer satisfaction for de-

\footnotetext{
${ }^{*}$ Corresponding author.
}

adfa, p. 1, 2011.

(C) Springer-Verlag Berlin Heidelberg 2011 
veloping service quality of health industries. Furthermore, many researches show that customer satisfaction has obvious relationship with product quality and service quality $[7,8]$. So improving service quality can be an effective way to increase customer satisfaction. SERVQUAL is proposed in 1988 by Parasuraman et al. [9]. And in 1991, they refined the original SERVQUAL instrument and reexamined its reliability and validity [10]. Perceived service quality is viewed as the degree and direction of discrepancy between consumer's perceptions and expectations, including five dimensions: tangibles, reliability, responsiveness, assurance, and empathy [11]. Service quality has become an important research topic in various industries due to its significant relationship to cost, profitability, customer satisfaction, customer retention, and service guarantee [12].

Many researchers have studied on hospital service and derived their assess dimensions $[13,14,15,16]$. In addition, hospital managers often pay much attention to direct medical treatment, supportive service such as foodservice may be ignored. But as mentioned above, foodservice is one of the most dissatisfied areas in Chinese hospital service. Toward hospital foodservice, Zhang et al. (2009) [1] conducted a questionnaire survey on five dimensions of hospital service. They found that logistics management was the most dissatisfied part. Dubé et al. (1994) [17] proposed seven dimensions that represented patients' perceptions of foodservice: food quality, service timeliness, service reliability, food temperature, attitude of the staff who deliver menus, attitude of the staff who serve meals, and customization. They emphasized the need for a comprehensive and differentiated approach in measuring and monitoring patients' satisfaction with foodservice. Among these literatures, SERVQUAL instrument is widely used. Meanwhile, factor analysis and structural equation modeling is the most popular method used to study on hospital foodservice and some related fields [14], [15], [18] At the same time, some other methods are also used to study hospital foodservice. Such as the Entropy method [13], and fuzzy VIKOR method [16].

To sum up, with the development of health industry, the demand for supportive service is increasing, so it's necessary to study on hospital foodservice. With considering the particularities of hospital, this paper proposes satisfaction model of Chinese hospital foodservice based on SERVQUAL. Combined with descriptive statistics and SEM, this paper analyzes the influence factors of patients' satisfaction with hospital foodservice and the influence degree of each factor.

This paper is organized into four sections. Section 2 explains the research conceptual model, while the research methodology and data analysis are discussed in Section 3. The final section discusses the conclusions and managerial suggestions based on this research.

\section{$2 \quad$ Hypotheses and Modeling}

Until now, there are lots of hospitals with over 4000 beds in China [19]. Owning to a great deal of patients, the food supply system in Chinese hospital is quite complicated. Besides, there are still some problems in medical insurance system, so the price of hospital service is an important part that people will consider. Additionally, compared with the previous studies [3], [17], and considering the opinions of several experts, and patients, the main factors for evaluating hospital foodservice satisfaction are iden- 
tified as: product quality, service, timeliness, and price reasonableness.

SERVQUAL has been widely used on assessing service quality. But considering the particularities of hospital, we modified SERVQUAL, and proposed STQPSERVQUAL (see Fig.1.). Based on SERVQUAL items [9], and to make the items suitable for hospital foodservice, there are 18 items in our model. And the 18 items are classified into a total satisfaction dimension and four influence factors. In addition, a five-point $(1,3,5,7,9)$ scale ranging from "Strongly agree" (9) to "Strongly disagree" (1) is adopted in our questionnaire. The items are as follow:

Total satisfaction: 1. Total satisfaction. 2. Satisfaction on food quality. 3. Satisfaction on service quality;

S--service: 4 . The delivery staffs are willing to help customers. 5 . The delivery staffs perform service dependably. 6 . The foodservice department tries to give you individual attention. 7. The delivery staffs know your needs;

P--price reasonableness: 8 . The price on menu is clear and definite. 9. The price is reasonable;

T--timeliness: 10. The foodservice department delivery meal at the time they promise to do so. 11. You receive prompt service from the delivery staff;

Q--product quality: 12 . The delivery vehicle and tableware are clean and neat. 13. There are abundant types of dishes. 14. There are plenty of vegetables in season. 15. The provided food is healthy balanced. 16. The nutrition of food can meet patients' need. 17. The provided food taste good. 18. The food temperature is appropriate.

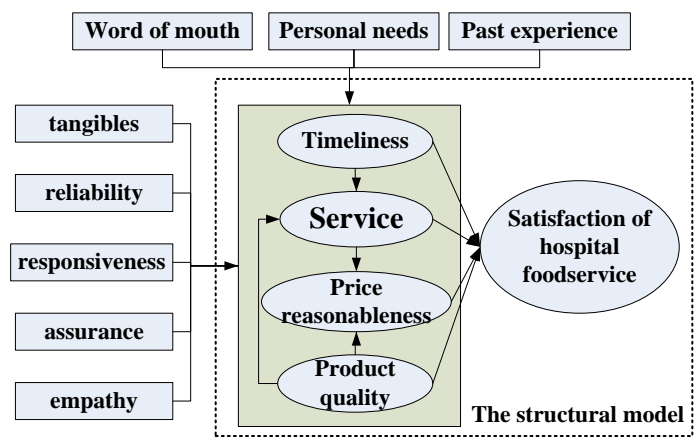

Fig. 1. STQP-SERVQUAL

There are some hypotheses to establish the model. Some researches show that product quality and service quality will impact customer satisfaction [7], [8], [20]. Service quality is considered the basis for customer satisfaction [20]. High product quality and service quality should archive high customer satisfaction.

H1: product quality has positive impact on patients' satisfaction with hospital foodservice; H2: service has positive impact on patients' satisfaction with hospital foodservice.

Timeliness is a kind of responsiveness, according to SERVQUAL [9,10], responsiveness is one of the five dimensions belong to service quality. Timeliness is related to customer satisfaction.

H3: timeliness has positive impact on patients' satisfaction with hospital foodservice; H4: timeliness has positive impact on service factor. 
For price reasonableness, Anderson et al. [5] suggest that price should impact customer satisfaction. They hold the opinion that value can be viewed as the ratio of perceived quality relative to price or benefits received to costs incurred. Customers' concerns about price fairness affect their product/service-choice behavior [21].

$\mathrm{H} 5$ : product quality has positive impact on price reasonableness factor; H6: service has positive impact on price reasonableness factor; $\mathrm{H} 7$ : price reasonableness has positive impact on patients' satisfaction with hospital foodservice.

Otherwise, we interviewed some patients. According to their opinions, the quality of products may influence perceived service quality in some degree. Because there are many customers mix the two kinds of qualities (product quality, service quality).

$\mathrm{H} 8$ : product quality has positive impact on service factor.

\section{$3 \quad$ Methodology and Data Analysis}

The data was collected in April 2014, in a hospital in China. The 281 pieces of data came from 8 departments, with Cronbach's $\alpha=0.951$. It shows good reliability. The sample data shows that the proportion of male and female is 1.1:1; patients are mainly over 50 years old.

\subsection{Descriptive Statistics}

The calculation method of satisfaction rate is as follow [22]:

For a respondent, if he/she signed 7 or 9 to an item, it means that this respondent

Table 1. Descriptive Statistics

\begin{tabular}{|c|c|c|c|c|c|c|c|c|}
\hline Factor & $\begin{array}{l}\text { Cronbach's } \\
\alpha\end{array}$ & Item & $\mathrm{N}$ & Mean & $\begin{array}{l}\text { Std } \\
\text { Dev }\end{array}$ & $\begin{array}{l}\text { Satisfaction } \\
\text { rate }\end{array}$ & $\begin{array}{c}\text { Factor } \\
\text { satisfaction } \\
\text { rate }\end{array}$ & $\begin{array}{l}\text { overall } \\
\text { satisfaction } \\
\text { rate }\end{array}$ \\
\hline \multirow{3}{*}{$\begin{array}{c}\text { Total } \\
\text { satisfaction }\end{array}$} & \multirow{3}{*}{0.843} & Item1 & 280 & 6.55 & 1.528 & $67.50 \%$ & \multirow{3}{*}{$51.60 \%$} & \multirow{18}{*}{$52.67 \%$} \\
\hline & & Item2 & 280 & 6.12 & 2.243 & $55.00 \%$ & & \\
\hline & & Item3 & 281 & 6.81 & 1.991 & $69.75 \%$ & & \\
\hline \multirow{4}{*}{ Service } & \multirow{4}{*}{0.964} & Item4 & 280 & 6.5 & 2.216 & $61.79 \%$ & \multirow{4}{*}{$52.67 \%$} & \\
\hline & & Item5 & 281 & 6.85 & 1.969 & $71.17 \%$ & & \\
\hline & & Item6 & 280 & 6.4 & 2.287 & $60.71 \%$ & & \\
\hline & & Item7 & 280 & 6.16 & 2.297 & $54.64 \%$ & & \\
\hline \multirow{2}{*}{$\begin{array}{c}\text { Price } \\
\text { reasonableness }\end{array}$} & \multirow{2}{*}{0.774} & Item8 & 281 & 5.01 & 3.112 & $41.28 \%$ & \multirow{2}{*}{$35.23 \%$} & \\
\hline & & Item9 & 279 & 5.16 & 2.534 & $37.63 \%$ & & \\
\hline \multirow[b]{2}{*}{ Timeliness } & \multirow{2}{*}{0.755} & Item10 & 281 & 7.58 & 1.813 & $83.27 \%$ & \multirow{2}{*}{$74.38 \%$} & \\
\hline & & Item11 & 281 & 7.26 & 1.957 & $76.51 \%$ & & \\
\hline \multirow{7}{*}{$\begin{array}{l}\text { Product } \\
\text { quality }\end{array}$} & \multirow{7}{*}{0.895} & Item12 & 279 & 7.2 & 1.968 & $73.84 \%$ & \multirow{7}{*}{$57.30 \%$} & \\
\hline & & Item13 & 278 & 6.2 & 2.375 & $56.83 \%$ & & \\
\hline & & Item14 & 278 & 6.03 & 2.365 & $52.16 \%$ & & \\
\hline & & Item15 & 279 & 6.5 & 2.161 & $63.44 \%$ & & \\
\hline & & Item16 & 277 & 6.44 & 2.092 & $62.09 \%$ & & \\
\hline & & Item17 & 279 & 5.96 & 2.171 & $50.18 \%$ & & \\
\hline & & Item18 & 277 & 7.25 & 1.958 & $77.62 \%$ & & \\
\hline
\end{tabular}


is satisfied with the item. For item $i(i=1,2, \ldots, 18)$, set $n_{i}$ as the number of respondents who have signed item $i$, and $a_{i}$ as the number of item satisfied respondents, then the satisfaction rate of item $i$ is calculated as: $a_{i} / n_{i}$. A respondent's score of a factor is calculated as his/her mean score of items belonging to this factor, if the score of a factor is bigger than or equal to 7, it means that this respondent is satisfied with the factor. For factor $j(j=1,2, \ldots, 5)$, set $m_{j}$ as the number of respondents who have signed items belonging to factor $j$, and $b_{j}$ as the number of factor satisfied respondents, then the satisfaction rate of factor $j$ is calculated as: $b_{j} / m_{\mathrm{j}}$. A respondent's score of the overall service is calculated as his/her mean score of all items, if the score of overall service is bigger than or equal to 7 , it means that this respondent is satisfied with the overall service. Set $N$ as the whole amount of respondents, $A$ as the number of overall satisfied respondents, then the satisfaction rate of overall service is calculated as: $A / N$.

See the results in Table 1. It shows that the mean scores of items are around 6. For factor satisfaction, Timeliness $74.38 \%$ rank first, followed by Product quality $57.3 \%$, Service $52.67 \%$, and Price reasonableness $35.23 \%$. And from standard deviation, we can see that the highest value comes from Price reasonableness. The scattered options show that there are big differences among respondents' opinions about Price reasonableness. Additionally, the overall satisfaction rate is $52.67 \%$. It means that there are only half respondents feel satisfied with the overall foodservice.

\subsection{Hospital Foodservice Satisfaction Model}

Structural equation modeling (SEM) is applied to analyze the influence degree of every factor. SEM provides a flexible and powerful means of simultaneously assessing the quality of measurement and examining causal relationships among constructs (latent variables or factors) [23].

In order to test a model's fit, some model evaluation criterions [23] such as the Chi-Square $\left(\chi^{2}\right)$ test statistic with respect to degrees of freedom, the Goodness of Fit Index (GFI), Root Mean Square Residual (RMR), Residual Means Squared Error (RMSEA), the Non-Normed Fit Index (NNFI), and the Comparative Fit Index (CFI) can be used. If the $\chi^{2} / \mathrm{df}$ value is less than 3 , the model is considered a good fit. The smaller the RMR, the better it is. It is excellent when GFI, NNFI, CFI $>0.95$, and RMSEA $<0.08$. And it is acceptable when GFI, NNFI, CFI are in $(0.9,0.95)$, and RMSEA is in $(0.08,0.1)$.

A measurement model is initially conducted before estimating the structural model. Conformity Factor Analysis (CFA) is conducted to fit the model. In this sample, we remove item 18 for its component value is less than 0.55 while all other items' component values are higher than 0.6 . We consider that item 18 have weak correlation with the factor. After data item reduction, the loading for all factors are sufficiently high. See the result in Table 2.

The fit of the measurement model is acceptable, with $\chi^{2} / \mathrm{df}=2.069 ; \mathrm{RMR}=0.040$, $\mathrm{GFI}=0.93, \mathrm{NNFI}=0.98, \mathrm{CFI}=0.99$ and RMSEA $=0.063$. The reliability coefficients are acceptable for all dimensions ranging from 0.755 (Timeliness) to 0.895 (Product quality), indicating internal consistency in measurement items. The overall estimate of internal consistency is 0.951 for hospital foodservice. Then according to STQPSERVQUAL (Fig 1.), we establish and test the structural model. 
Table 2. Results of Conformity Factor Analysis

\begin{tabular}{lccccc}
\hline Dimension & $\begin{array}{c}\text { Number } \\
\text { of cases }\end{array}$ & $\begin{array}{c}\text { Number } \\
\text { of items }\end{array}$ & $\begin{array}{l}\text { Number of } \\
\text { removed items }\end{array}$ & $\begin{array}{l}\text { Cronbach's } \\
\text { alpha }\end{array}$ & $\begin{array}{l}\text { Component } \\
\text { loading range }\end{array}$ \\
\hline Service & 280 & 4 & 0 & 0.864 & $0.72-0.83$ \\
Price reasonable & 279 & 2 & 0 & 0.774 & $0.67-0.94$ \\
Timeliness & 281 & 2 & 0 & 0.755 & $0.73-0.84$ \\
Product quality & 277 & 7 & 1 & 0.895 & $0.62-0.83$ \\
\hline
\end{tabular}

Establishing structural model is to find the relationship between each factor, test our hypotheses of STQP-SERVQUAL. According to the structural and measurement equations, implement the model on LISREL with maximum likelihood estimation procedure. The fit of the model is acceptable, with $\chi^{2} / \mathrm{df}=2.152 ; \mathrm{RMR}=0.040$, $\mathrm{GFI}=0.91, \mathrm{NNFI}=0.98, \mathrm{CFI}=0.99, \mathrm{RMSEA}=0.065$. See the outcome in Table 3 .

Table 3. Standard estimates of the model

\begin{tabular}{|c|c|c|c|c|c|c|c|c|}
\hline Hypothesis & Endogenous variable & & Exogenous variable & estimate & S.E. & $\mathrm{t}$ & $\mathrm{P}$ & Result \\
\hline H1 & satisfaction & $\leftarrow$ & product quality & 0.73 & 0.12 & 6.17 & 0.000 & Supported \\
\hline $\mathrm{H} 2$ & satisfaction & $\leftarrow$ & service & 0.51 & 0.13 & 4.02 & 0.000 & Supported \\
\hline $\mathrm{H} 3$ & satisfaction & $\leftarrow$ & timeliness & -0.14 & 0.12 & -1.12 & 0.264 & Not supported \\
\hline $\mathrm{H} 4$ & service & $\leftarrow$ & timeliness & 0.65 & 0.1 & 6.69 & 0.000 & Supported \\
\hline H5 & price reasonableness & $\leftarrow$ & product quality & 0.43 & 0.12 & 3.76 & 0.000 & Supported \\
\hline H6 & price reasonableness & $\leftarrow$ & service & 0.25 & 0.08 & 3.04 & 0.003 & Supported \\
\hline $\mathrm{H} 7$ & satisfaction & $\leftarrow$ & price reasonableness & 0.07 & 0.07 & 0.96 & 0.338 & Not supported \\
\hline $\mathrm{H} 8$ & service & $\leftarrow$ & product quality & 0.48 & 0.1 & 4.71 & 0.000 & Supported \\
\hline
\end{tabular}

From the results of SEM, we find that according to the sample data, two hypotheses of STQP-SERVQUAL are not tenable, i.e. H3, H7. Timeliness has no significant direct impact on total satisfaction. Its indirect impact on total satisfaction goes through the variable "Service". We can conclude that Service provide a buffer to the impact caused by Timeliness. On the one hand, good service will make up for dissatisfaction on Timeliness; on the other hand, bad service will worsen the influence caused by dissatisfaction on Timeliness. At the same time, Price reasonableness has no significant impact on total satisfaction. This result does make sense for patients usually think highly of nutrition, sometimes price seems less important. But the descriptive statistics remind us that Price reasonableness is the lowest satisfied factor. So Price reasonableness can't be ignored either.

Furthermore, from Table 3 we can conclude: (1) Service and Product quality have direct influence to total satisfaction. The influence degree of Product quality (0.73) is bigger, while Service's is 0.51 . (2) Apart for direct influence, Product quality and Timeliness have indirect influence to total satisfaction. And by indirect effect, the influence degree of Timeliness $(\mathrm{H} 4, \mathrm{H} 2)$ is $0.65 \times 0.51=0.3315$. (3) For comprehensive influence, Product quality $(0.73+0.48 \times 0.51=0.9748)$ rank first, followed by Service (0.51), and Timeliness $(0.3315)$.

\section{Discussions and Conclusions}

As high-quality service has become a requirement among hospitals, and to support 
managerial decision making, this paper investigates the linkages among service, timeliness, product quality, price reasonableness, and customer satisfaction in a hospital.

From the sample data, the results of descriptive statistics and SEM show that the satisfaction rate of Service is $52.67 \%$ with influence degree 0.51 . Service has a positive significant impact on hospital foodservice satisfaction (H2), but among Service items, item 7"The delivery staffs know your needs" gets the lowest satisfaction rate. It suggests that the department should communicate more with patients, getting to know their needs. Timeliness has an indirect impact on hospital foodservice satisfaction $(\mathrm{H} 4$, $\mathrm{H} 2$ ) with satisfaction rate $74.38 \%$ and influence degree 0.3315 . Its indirect impact on total satisfaction goes through the variable "Service". Consequently, besides delivery on time, staffs should provide good service. Or patients will be dissatisfied with both Timeliness and Service. Product quality has a positive significant impact on hospital foodservice satisfaction $(\mathrm{H} 1)$, with satisfaction rate $57.3 \%$ and influence degree 0.9748 . Product quality is the core of foodservice, it has highest influence degree. But the satisfaction rate is just over fifty percent, especially item 17 "The provided food taste good". This item gets the lowest satisfaction rate in Product quality. Foodservice department should work on it to make meals more delicious while ensure the nutrition and being suitable for patients. In addition, the impact on hospital foodservice satisfaction caused by Price reasonableness is not significant. Moreover, Price reasonableness gets the lowest satisfaction rate $35.23 \%$, and biggest standard deviation. It suggests that the department should analyze meal cost more precisely, expand ways to publish price information. Then make price more reasonable and clear.

In this paper, STQP-SERVQUAL was proposed to analyze influence factors of patients' satisfaction with hospital foodservice. The model covers food quality and service attitude which most past studies focus on. Moreover, considering the particularities of hospital foodservice, the model covers timeliness and price reasonableness. The results suggest that Service, Timeliness, and Product quality have positive significant impacts on patients' satisfaction with hospital foodservice. Moreover, the impact caused by Price reasonableness is not significant. The results in this paper are helpful for hospital managers and other health industries to improve foodservice satisfaction.

Acknowledgement. This research was supported by the National Science Foundation for the Key Program of NSFC (Grant no. 71131006).

\section{References}

1. Zhang, G., He, X., Guo, L.: Satisfaction survey analysis of discharged patients. (In Chinese). Chinese Health Quality Management. 16(1),40-41(2009)

2. Zhang, J.: A survey on inpatient's satisfaction degree in a tertiary hospital. (In Chinese). Shandong University, Shandong (2007)

3. Dall’Oglio, I., Nicolò, R., Ciommo, V.D., Bianchi, N., Ciliento, G., Gawronski, O., Pomponi, M., Roberti, M., Tiozzo, E., Raponi, M.: A Systematic Review of Hospital Foodservice Patient Satisfaction Studies. Journal of the Academy of Nutrition and Dietetics. 115(4), 567-584 (2015)

4. Oliver, R.L.: Satisfaction: a behavioral perspective on the consumer. (2nd ed.) M.E. Sharpe, Armonk, N.Y. (2010)

5. Anderson, E.W., Fornell, C., Lehmann, D.R.: Customer Satisfaction, Market Share, and 
Profitability: Findings from Sweden. Journal of Marketing. 58(3), 53-66 (1994)

6. Johnson, M.D.: Customer satisfaction. International Encyclopedia of the Social \& Behavioral Sciences (Second Edition). Elsevier (2015)

7. Anderson, E.W., Sullivan, M.W.: The Antecedents and Consequences of Customer Satisfaction for Firms. Marketing Science. 12(2), 125-143 (1993)

8. Hussain, R., Nasser, A.A., Hussain, Y.K.: Service quality and customer satisfaction of a UAE-based airline: An empirical investigation. Journal of Air Transport Management. 42 167-175 (2015)

9. Parasuraman, A., Zeithaml, V.A., Berry, L.L.: SERVQUAL: A Multiple-Item Scale for Measuring Consumer Perceptions of Service Quality. Journal of Retailing. 64(1),12-40 (1988)

10. Parasuraman, A., Berry, L.L., Zeithaml, V.A.: Refinement and Reassessment of the SERVQUAL Scale. Journal of Retailing. 67(4), 420-450 (1991)

11. Fitzsimmons, J.A., Fitzsimmons, M.J.: SERVICE MANAGEMENT Operations, Strategy, and Information Technology (Third Edition). McGraw-Hill, Inc., New York (2001)

12. Sohail, M.S.: Service quality in hospitals: More favorable than you might think. Managing Service Quality. 13(3), 197-206 (2003)

13. Handayani, P.W., Hidayanto, A.N., Sandhyaduhita, P.I., Kasiyah, Ayuningtyas, D.: Strategic hospital services quality analysis in Indonesia. Expert Systems with Applications. 42, 3067-3078 (2015)

14. Butt, M.M., de Run, E.C.: Private healthcare Quality: Applying a SERVQUAL model. International Journal of Health Care Quality Assurance. 23(7), 658-673 (2010)

15. Untachai, S.: Modeling Service Quality in Hospital as a Second Order Factor, Thailand. Social and Behavioral Sciences Symposium, 4th International Science, Social Science, Engineering and Energy Conference 2012 (I-SEEC 2012). Social and Behavioral Sciences. $88: 118-133(2013)$

16. Chang, T.-H.: Fuzzy VIKOR method: A case study of the hospital service evaluation in Taiwan. Information Sciences. 271, 196-212 (2014)

17. Dubé, L., Trudeau, E., Bélanger, M.C.: Determining the complexity of patient satisfaction with foodservices. Journal of the American Dietetic Association. 94(4), 394-401 (1994)

18. Gao, Q., Cao, Z., Sheng, P.: Satisfaction research for student canteen service based on SEM. (In Chinese). Journal of Southwest University for Nationalities. 6,255-259 (2006)

19. Wang, S., Rao, K.: The developing of beds in Chinese hospitals: from an international point of view. (In Chinese). Chinese Hospitals.16 (9), 13-16 (2012)

20. Clemes M., Gao C., Kao T., Choong M.: An empirical analysis of customer satisfaction in international air travel. Innovative Marketing. 4(4),49-62 (2008)

21. Ryu, K., Han, H.: Influence of the quality of food, service, and physical environment on customer satisfaction and behavioral intention in quick-casual restaurants: moderating role of perceived price. Journal of Hospitality and Tourism Research. 34(3), 310-329 (2010)

22. Li Q. The Customer Satisfaction Model for Management Improvement of Medical Service. (In Chinese). Sichuan University, Sichuan (2006)

23. Wang, J., Wang, X.: Structural Equation Modeling: Applications Using Mplus. Higher education press, Beijing (2012) 